\title{
PREPARATION AND PROPERTIES OF Ni(IV), Pd(IV) AND Pt(IV) TRISDITHIOCARBAMATO COMPLEXES
}

\author{
BY \\ J. WILLEMSE and J. A. CRAS \\ (Laboratory for Inorganic Chemistry, University of Nijmegen, Toernooiveld, Nijmegen, \\ The Netherlands)
}

Oxidation of $N, N$-dialkyldithiocarbamato $\left(\mathrm{R}_{2} \mathrm{dtc}\right)$ complexes of $\mathrm{Ni}(\mathrm{II}), \mathrm{Pd}(\mathrm{II})$ and $\mathrm{Pt}$ (II) with 3,5 -bis $\left(N, N\right.$-dialkyliminium)-1,2,4-trithiolane ion $\left(\mathrm{R}_{4}\right.$ bitt) ${ }^{2+}$ containing compounds and with $M\left(R_{2} \mathrm{dtc}\right) \mathbf{X}_{2}(\mathbf{M}=\mathrm{Cu}, \mathrm{Au} ; \mathrm{X}=\mathrm{Cl}, \mathrm{Br})$ is reported. From the oxidation of $\mathrm{Ni}\left(\mathbf{R}_{2} \mathrm{dtc}\right)_{2}$ the componds $\mathrm{Ni}\left(\mathbf{R}_{2} \mathrm{dtc}\right)_{3} \mathrm{X}$ $\left(\mathrm{X}=\mathrm{Cl}, \mathrm{Br}, \mathrm{FeCl}_{4}\right.$ ) were obtained. The oxidation of $\mathrm{Pd}\left(\mathrm{R}_{2} \mathrm{dtc}\right)_{2}$ with $\mathbf{R}_{4}$ bitt $^{2+} \mathrm{Cu}_{2} \mathrm{X}_{6}^{2-}(\mathrm{X}=\mathrm{Cl}, \mathrm{Br})$ resulted in the new compounds $\left[\mathrm{Pd}\left(\mathbf{R}_{2} \mathrm{dtc}\right)_{3}\right]_{2}$ $\mathrm{Cu}_{2} \mathrm{X}_{6}$.

The new compound $\mathrm{Pt}\left(\mathrm{R}_{2} \mathrm{dtc}\right)_{3} \mathrm{CuBr}_{2}$ could be obtained by the oxidation of $\mathrm{Pt}\left(\mathrm{R}_{2} \mathrm{dtc}\right)_{2}$ with either $\left(\mathrm{R}_{4}\right.$ bitt) ${ }^{2+} \mathrm{Cu}_{2} \mathrm{Br}_{6}^{2-}$ or $\mathrm{Cu}\left(\mathrm{R}_{2} \mathrm{dtc}\right) \mathrm{Br}_{2}$, or by the reaction of $\mathrm{Pt}\left(\mathrm{R}_{2} \mathrm{dtc}\right)_{3} \mathrm{Br}$ with $\mathrm{CuBr}_{2}$. The analogous copper chloride compound was prepared from $\left(\mathbf{R}_{4}\right.$ bitt) ${ }^{2+} \mathrm{Cu}_{2} \mathrm{Cl}_{6}^{2-}$ with $\mathrm{Pt}\left(\mathbf{R}_{2} \mathrm{dtc}\right)_{2}$. The compound $\mathrm{Pt}\left(\mathbf{R}_{2} \mathrm{dtc}\right)_{3} \mathrm{AuBr}_{2}$ was prepared from $\mathrm{Pt}\left(\mathbf{R}_{2} \mathrm{dtc}\right)_{2}$ and $\mathrm{Au}\left(\mathbf{R}_{2} \mathrm{dtc}\right) \mathrm{Br}_{2}$. The metal-sulfur infrared stretching frequencies are in accord with the assumption that in all these compounds the metal atoms $\mathrm{Ni}(\mathrm{IV}), \mathrm{Pd}(\mathrm{IV})$ and $\mathrm{Pt}(\mathrm{IV})$ have a $D_{3}$ symmetry. Conductivity measurements showed the platinum complexes to be $1: 1$ electrolytes.

\section{Introduction}

The excessive halogenation of some dithiocarbamato complexes e.g. $\mathrm{Fe}\left(\mathrm{R}_{2} \mathrm{dtc}\right)_{3}$ and $\left[\mathrm{Cu}\left(\mathrm{R}_{2} \mathrm{dtc}\right)\right]_{4}$ was earlier supposed to yield $\left[\left(\mathrm{R}_{2} \mathrm{dtc}\right)_{2}\right]^{2+}\left[\mathrm{FeX}_{4}^{-}\right]_{2}$ and $\left[\left(\mathrm{R}_{2} \mathrm{dtc}\right)_{2}\right]^{2-}\left[\mathrm{Cu}_{2} \mathbf{X}_{6}\right]^{2+}$. The structure of the $\left[\left(\mathbf{R}_{2} \mathrm{dtc}\right)_{2}\right]^{2+}$ ion was postulated by Willemse and Steggerda ${ }^{2}$. Further investigations, however, indicated the ion to be composed of a trithiolane ring. The most convincing information was obtained by an $\mathrm{X}$-ray analysis of the compound, which was assumed to be $\left[\left(\mathrm{et}_{2} \mathrm{dtc}\right)_{2}\right]^{2+}$

1 P. T. Beurskens, J. A. Cras, Th. W. Hummelink and J. G. M. van der Linden, Rec. Trav. Chim. 89, 984 (1970).

2 J. Willemse and J. J. Steggerda, Chem. Comm. 1123 (1969). 
$\left[\mathrm{Hg}_{2} \mathrm{I}_{6}\right]^{2-}$. This analysis revealed the compound has to be formulated as $^{3}$ :

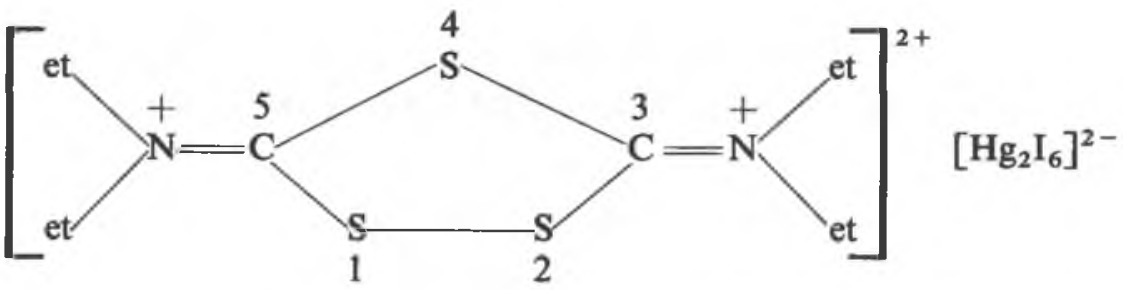

i.e., 3,5-bis( $N, N$-diethyliminium)-1,2,4-trithiolane-di- $\mu$-iodotetraiododimercurate (II).

For the 3,5-bis $(N, N$-dialkyliminium)-1,2,4-trithiolane ion we shall use the notation $\left[\mathbf{R}_{4} \text { bitt }\right]^{2+}$.

In a previous communication ${ }^{1}$ we reported the synthesis of the compound $\left[\mathrm{Au}\left(\mathrm{bu}_{2} \mathrm{dtc}\right)_{2}\right]^{+}\left[\mathrm{CuBr}_{2}\right]^{-}$by the following reactions:

$\left[\mathrm{Au}\left(\mathrm{bu}_{2} \mathrm{dtc}\right)_{2}\right]^{+} \mathrm{Br}^{-}+\mathrm{CuBr}_{2} \longrightarrow\left[\mathrm{Au}\left(\mathrm{bu}_{2} \mathrm{dtc}\right)_{2}\right]^{+}\left[\mathrm{CuBr}_{2}\right]^{-}+\frac{1}{2} \mathrm{Br}_{2}$ $\left[\mathrm{Au}\left(\mathrm{bu}_{2} \mathrm{dtc}\right)\right]_{2}+\left[\mathrm{bu}_{4} \mathrm{bitt}\right]^{2+}\left[\mathrm{Cu}_{2} \mathrm{Br}_{6}\right]^{2-} \longrightarrow$

$$
2\left[\mathrm{Au}\left(\mathrm{bu}_{2} \mathrm{dtc}\right)_{2}\right]^{+}\left[\mathrm{CuBr}_{2}\right]^{-}+\mathrm{Br}_{2}
$$

As we are interested in the oxidizing properties of compounds, containing the $\left[\mathbf{R}_{\mathbf{4}} \text { bitt }\right]^{2+}$ ion, we carried out some reactions of these compounds with the dithiocarbamato complexes of nickel, palladium and platinum and with the zinc, cadmium and mercury dithiocarbamates.

The results of the reactions with the former three compounds are reported in this communication, whereas those results with the latter three compounds will be dealt with in a forthcoming publication.

\section{Experimental section ${ }^{4}$}

The starting materials were obtained as described in the literature: $\mathrm{Ni}\left(\mathrm{et}{ }_{2} \mathrm{dtc}\right)_{2}$ from $\mathrm{Na}$ (et $\left.{ }_{2} \mathrm{dtc}\right) \cdot 3 \mathrm{H}_{2} \mathrm{O}$ (Baker) and $\mathrm{NiCl}_{2} \cdot 6 \mathrm{H}_{2} \mathrm{O}$ (Merck); $\mathrm{Ni}\left(\mathrm{bu}_{2} \mathrm{dtc}\right)_{2}, \mathrm{Pd}\left(\mathrm{bu}_{2} \mathrm{dtc}\right)_{2}$ and $\mathrm{Pt}\left(\mathrm{bu}_{2} \mathrm{dtc}\right)_{2}$ following the general procedure for the synthesis of dithiocarbamates ${ }^{5}$

${ }^{3}$ P. T. Beurskens, W. P. J. H. Bosman and J. A. Cras, J. Cryst. Mol. Struct. 2, (1972).

${ }^{4}$ We gratefully acknowledge the assistance of Mr. W. F. J.H. Sieben in the preparative work.

5 G. D. Thorn and R. A. Ludwig, The Dithiocarbamates and Related Compounds, Elsevier, Amsterdam (1962). 
from $\mathrm{NiCl}_{2} \cdot 6 \mathrm{H}_{2} \mathrm{O}, \mathrm{K}_{2} \mathrm{PdCl}_{4}$ (Drijfhout) and $\mathrm{K}_{2} \mathrm{PtCl}_{4}$ (Drijfhout), respectively. The preparation of the following compounds is described in the given references: [ $\mathrm{et}_{4} \mathrm{bitt}^{2+}$ $\left[\mathrm{FeCl}_{4}^{-}\right]_{2}{ }^{2},\left[\mathrm{bu}_{4} \mathrm{bitt}\right]^{2+}\left[\mathrm{Cu}_{2} \mathrm{Cl}_{6}\right]^{2-6},\left[\mathrm{bu}_{4} \text { bitt }\right]^{2+}\left[\mathrm{Cu}_{2} \mathrm{Br}_{6}\right]^{2-6}, \mathrm{Cu}\left(\mathrm{bu}_{2} \mathrm{dtc}\right) \mathrm{Br}_{2}{ }^{7}, \mathrm{Au}-$ (bu $\left.{ }_{2} \mathrm{dtc}\right) \mathrm{Br}_{2}{ }^{8}$ and $\left[\mathrm{Pt}\left(\mathrm{bu}_{2} \mathrm{dtc}\right)_{3}\right]^{+} \mathrm{Br}^{-9}$.

Analyses. Heavy metals were analysed by atomic absorption photometric methods, using dilute aqua regia solutions as standards. The other elemental analyses were carried out in the micro-analytical department of this university.

\section{Preparations}

I. Reactions of $\left[R_{4} \text { bitt }\right]^{2+}$ containing compounds with the dithiocarbamato complexes of nickel, palladium and platinum

a) Reaction of $\mathrm{Ni}\left(e t_{2} \mathrm{dtc}\right)_{2}$ with $\left[\mathrm{et}_{4} \mathrm{bitt}\right]^{2+}\left[\mathrm{FeCl}_{4}\right]_{2}$

To a solution of one mole of $\mathrm{Ni}\left(\mathrm{et}_{2} \mathrm{dtc}\right)_{2}$ in chloroform, a suspension of half a mole of $\left[\mathrm{et}_{4} \mathrm{bitt}^{2+}\left[\mathrm{FeCl}_{4}^{-}\right]_{2}\right.$ in chloroform was added. A clear solution was obtained by stirring the reaction mixture for half an hour. After addition of ligroin $\left(40-60^{\circ}\right)$, a crystalline product of $\left[\mathrm{Ni}\left(\mathrm{et}_{2} \mathrm{dtc}\right)_{3}\right]^{+}\left[\mathrm{FeCl}_{4}^{-}\right]$was obtained.

b) Reaction of $\mathrm{Ni}\left(\mathrm{bu}_{2} \mathrm{dtc}\right)_{2}$ with $\left[\mathrm{bu} \mathrm{u}_{4} \mathrm{bitt}\right]^{2+}\left[\mathrm{Cu}_{2} \mathrm{Br}_{6}\right]^{2-}$ and with $\left[\mathrm{bu}_{4} \mathrm{bitt}\right]^{2+}\left[\mathrm{AuBr}_{4}^{-}\right]_{2}$

When the same procedure was used for these reaction components as described for the reaction of $\mathrm{Ni}\left(\mathrm{et}_{2} \mathrm{dtc}\right)_{2}$ with $\left[\mathrm{et}_{4} \mathrm{bitt}^{2+}\left[\mathrm{FeCl}_{4}^{-}\right]_{2}\right.$, oily products were obtained. This complication could be avoided when the following modification was used. To the chloroform solution of the reaction mixture an equal volume of water was added and this mixture was shaken for twelve hours. After addition of ligroin (40-60) or diethyl ether to the chloroform layer, a precipitate of $\left[\mathrm{Ni}\left(\mathrm{bu}_{2} \mathrm{dtc}\right)_{3}\right]^{+} \mathrm{Br}$ was obtained in both cases. In the aqueous layers copper and gold, respectively, could be detected.

c) Oxidation of $\mathrm{Pd}\left(\mathrm{bu} \mathrm{u}_{2} d t c\right)_{2}$ with $\left[\mathrm{bu}_{4} \mathrm{bitt}\right]^{2+}\left[\mathrm{Cu}_{2} \mathrm{X}_{6}\right]^{2-}(\mathrm{X}=\mathrm{Cl}, \mathrm{Br})$

To solutions of one mole $\mathrm{Pd}\left(\mathrm{bu}_{2} \mathrm{dtc}\right)_{2}$ in chloroform, suspensions of half a mole of $\left[\mathrm{bu}_{4} \text { bitt }\right]^{2+}\left[\mathrm{Cu}_{2} \mathrm{Cl}_{6}\right]^{2-}$ and $\left[\mathrm{bu}_{4} \text { bitt }\right]^{2+}\left[\mathrm{Cu}_{2} \mathrm{Br}_{6}\right]^{2-}$

6 H. C. Brinkhoff, Thesis, Nijmegen (1970).

7 P. T. Beurskens, J. A. Cras and J. J. Steggerda, Inorg. Chem. 7, 810 (1968).

8 H. J. A. Blaauw, R. J. Nivard and G. J. M. van der Kerk, J. Organometal. Chem. 2, 236 (1964).

9 $J$. A. Cras and J. Willemse, to be published. 
were added. Clear solutions were obtained by stirring the reaction mixtures for half an hour. After addition of diethyl ether to the solutions a red crystalline compound $\mathrm{Pd}\left(\mathrm{bu}_{2} \mathrm{dtc}\right)_{3} \mathrm{CuCl}_{3}$ (m.p. $104-105^{\circ}$ ) and a black-brown crystalline compound $\mathrm{Pd}\left(\mathrm{bu}_{2} \mathrm{dtc}\right)_{3} \mathrm{CuBr}_{3}$ (decomp. $>90^{\circ}$ ) was obtained in the respective mixtures. Some coprecipitated $\mathrm{Cu}\left(\mathrm{bu}_{2} \mathrm{dtc}\right) \mathrm{Cl}_{2}$ and $\mathrm{Cu}\left(\mathrm{bu}_{2} \mathrm{dtc}\right) \mathrm{Br}_{2}$ could be removed by washing thoroughly with diethyl ether.

Anal. Calcd. for $\mathrm{PdC}_{27} \mathrm{H}_{54} \mathrm{~N}_{3} \mathrm{~S}_{6} \mathrm{CuCl}_{3}: \mathrm{Pd}, 11.96 ; \mathrm{C}, 36.46 ; \mathrm{H}$, $6.13 ; \mathrm{N}, 4.73 ; \mathrm{Cu}, 7.14 ; \mathrm{Cl}, 11.96$.

Found: $\mathrm{Pd}, 12.05 ; \mathrm{C}, 36.59 ; \mathrm{H}, 6.07 ; \mathrm{N}, 4.86 ; \mathrm{Cu}, 7.20 ; \mathrm{Cl}$, 12.40 .

Calcd. for $\mathrm{PdC}_{27} \mathrm{H}_{54} \mathrm{~N}_{3} \mathrm{~S}_{6} \mathrm{CuBr}_{3}: \mathrm{Pd}, 10.40 ; \mathrm{C}, 31.70 ; \mathrm{H}$, $5.33 ; \mathrm{N}, 4.11 ; \mathrm{Cu}, 6.21 ; \mathrm{Br}, 23.44$.

Found: $\mathrm{Pd}, 10.44 ; \mathrm{C}, 31.13 ; \mathrm{H}, 5.11 ; \mathrm{N}, 4.11 ; \mathrm{Cu}, 6.36 ; \mathrm{Br}$, 23.69.

d) Oxidation of $\mathrm{Pt}\left(\mathrm{bu} \mathrm{u}_{2} d t c\right)_{2}$ with $\left[\mathrm{bu}_{4} \text { bitt }\right]^{2+}\left[\mathrm{Cu} \mathrm{X}_{6}\right]^{2-}(\mathrm{X}=\mathrm{Cl}, \mathrm{Br})$ The same procedure as described for the oxidation of $\operatorname{Pd}\left(\mathrm{bu}_{2} \mathrm{dtc}\right)_{2}$ was performed with the platinum compound. Yellow crystals of $\mathrm{Pt}\left(\mathrm{bu}_{2} \mathrm{dtc}\right)_{3} \mathrm{CuX}_{2}(\mathrm{X}=\mathrm{Cl}, \mathrm{Br})$ were obtained with melting points $153-154^{\circ}$ and $141.5-142.5^{\circ}$, respectively.

Anal. Calcd. for $\mathrm{PtC}_{27} \mathrm{H}_{54} \mathrm{~N}_{3} \mathrm{~S}_{6} \mathrm{CuCl}_{2}$ : C, 34.40; H, 5.79; N, 4.46; $\mathrm{Cu}, 6.74 ; \mathrm{Cl}, 7.52$.

Found: C, 33.90; H, 5.50; N, 4.53; Cu, 6.74; Cl, 7.76.

Calcd. for $\mathrm{PtC}_{27} \mathrm{H}_{54} \mathrm{~N}_{3} \mathrm{~S}_{6} \mathrm{CuBr}_{2}$ : C, 31.43; H, 5.29; N, 4.07; $\mathrm{S}, 18.65 ; \mathrm{Cu}, 6.16 ; \mathrm{Br}, 15.49$.

Found: C, 31,36; H, 5.46; N, 4.06; S, $18.47 ; \mathrm{Cu}, 6.20 ; \mathrm{Br}$, 15.25 .

II. Oxidation of $\mathrm{Ni}\left(b u_{2} d t c\right)_{2}, P d\left(b u_{2} d t c\right)_{2}$ and $\mathrm{Pt}\left(b u_{2} d t c\right)_{2}$ with $\mathrm{Cu}\left(b u_{2} d t c\right) B r_{2}$ and with $\mathrm{Au}\left(b u_{2} d t c\right) \mathrm{Br}_{2}$

Solutions of one mole of $\mathrm{Ni}\left(\mathrm{bu}_{2} \mathrm{dtc}\right)_{2}$ in chloroform were added to a solution of one mole of $\mathrm{Cu}\left(\mathrm{bu}_{2} \mathrm{dtc}\right) \mathrm{Br}_{2}$ or $\mathrm{Au}\left(\mathrm{bu}_{2} \mathrm{dtc}\right) \mathrm{Br}_{2}$ in chloroform. Oily substances were obtained after addition of diethyl ether to the reaction mixtures. Whereas infrared spectra of these oils indicated impure $\mathrm{Ni}\left(\mathrm{bu}_{2} \mathrm{dtc}\right)_{3} \mathrm{Br}$ to be present, no attempts were made to purify the products. When the same procedures were carried out for $\mathrm{Pd}\left(\mathrm{bu}_{2} \mathrm{dtc}\right)_{2}$ no reactions were observed at all. $\mathrm{Pt}\left(\mathrm{bu}_{2} \mathrm{dtc}\right)_{3} \mathrm{CuBr}_{2}$ and 
$\mathrm{Pt}\left(\mathrm{bu}_{2} \mathrm{dtc}\right)_{3} \mathrm{AuBr}_{2}$ however could be obtained in $90 \%$ and $85 \%$ yield, respectively, using the procedure described above. The melting point of $\mathrm{Pt}\left(\mathrm{bu}_{2} \mathrm{dtc}\right)_{3} \mathrm{AuBr}_{2}$ is $135.5-137^{\circ}$.

Anal. Calcd. for $\mathrm{PtC}_{27} \mathrm{H}_{54} \mathrm{~N}_{3} \mathrm{~S}_{6} \mathrm{AuBr}_{2}$ : C, 27.83; H, 4.68; N, 3.61; $\mathrm{Au}, 16.9 ; \mathrm{Br}, 13.7$.

Found: $\mathrm{C}, 27.45 ; \mathrm{H}, 4.45 ; \mathrm{N}, 3.63 ; \mathrm{Au}, 17.3 ; \mathrm{Br}, 13.9$.

\section{Reaction of $\mathrm{Pt}\left(b u_{2} d t c\right)_{3} \mathrm{Br}$ with $\mathrm{CuBr}_{2}$}

As in the reaction of $\left[\mathrm{Au}\left(\mathrm{bu}_{2} \mathrm{dtc}\right)_{2}\right]^{+} \mathrm{Br}^{-}$with $\mathrm{CuBr}_{2}$, which yields $\left[\mathrm{Au}\left(\mathrm{bu}_{2} \mathrm{dtc}\right)_{2}\right]^{+}\left[\mathrm{CuBr}_{2}\right]^{-}+\frac{1}{2} \mathrm{Br}_{2}{ }^{1}\left[\mathrm{Pt}\left(\mathrm{bu}_{2} \mathrm{dtc}\right)_{3}\right]^{+}\left[\mathrm{CuBr}_{2}\right]^{-}$, could be obtained from solutions of $\left.\left[\mathrm{Pt}^{(} \mathrm{bu}_{2} \mathrm{dtc}\right)_{3}\right]^{+} \mathrm{Br}^{-}$and $\mathrm{CuBr}_{2}$ in absolute ethanol.

\section{Physical measurements}

Infrared spectra in the region of 4000-625 $\mathrm{cm}^{-1}$ were examined in $\mathrm{KBr}$ pellets with a Perkin-Elmer 257 infrared spectrophotometer. In the region $700-200 \mathrm{~cm}^{-1}$ the spectra were measured with an Hitachi EPI-L instrument. These spectra were recorded in Nujol mulls unless otherwise stated.

Magnetic susceptibility measurements were performed with a standard Gouy-type balance.

Conductivity. The molar conductivities were measured in nitrobenzene solutions at $25^{\circ}$.

Nuclear Magnetic Resonance. The NMR spectra were recorded on a Varian HA-100 instrument.

\section{Results and discussion}

The compounds $\mathrm{Pd}\left(\mathrm{bu}_{2} \mathrm{dtc}\right)_{3} \mathrm{CuCl}_{3}$ and $\mathrm{Pd}\left(\mathrm{bu}_{2} \mathrm{dtc}\right)_{3} \mathrm{CuBr}_{3}$ decompose in several organic solvents, therefore conductivity measurements, NMR and electronic spectra could not be taken. With the aid of UV techniques $\mathrm{Pd}\left(\mathrm{bu}_{2} \mathrm{dtc}\right)_{2}$ and $\mathrm{Cu}\left(\mathrm{bu}_{2} \mathrm{dtc}\right) \mathrm{X}_{2}(\mathrm{X}=\mathrm{Cl}$ and $\mathrm{Br}$, respectively) could be proved to be the decomposition products in chloroform.

Magnetic susceptibility measurements indicated that in the temperature range $103-293^{\circ} \mathrm{K}$ the Curie-Weiss law is followed. 
For the chlorine compound a Weiss temperature of $-5^{\circ} \mathrm{K}$ and a magnetic moment of $2.10 \mathrm{BM}$ are found, the values for the bromine compound are $0^{\circ} \mathrm{K}$ and $2.06 \mathrm{BM}$, respectively. The results agree with the assumption that diamagnetic $\mathrm{Pd}(\mathrm{IV})$ and $\mathrm{Cu}(\mathrm{II})\left(\mathrm{S}=\frac{1}{2}\right)$ are present in these compounds. In the far infrared spectra the copper halogen stretching frequencies indicated the presence of dimeric halogenocuprate ions (Table I).

In the planar ions $\left[\mathrm{Cu}_{2} \mathrm{X}_{6}\right]^{2-10}$ two terminal metal halogen stretching frequencies $\left(B_{2 v}\right.$ and $\left.B_{3 v}\right)$ and two bridging frequencies $\left(B_{2 u}\right.$ and $B_{3 v}$ as well) should be present. One of the bridging frequencies in $\left\{\left[\mathrm{Pd}\left(\mathrm{bu}_{2} \mathrm{dtc}\right)_{3}\right]^{+}\right\}_{2}\left[\mathrm{Cu}_{2} \mathrm{Br}_{6}\right]^{2-}$ could not be observed as it is expected below $200 \mathrm{~cm}^{-1}$. The other values are in agreement with those found for the compounds $\mathrm{K}_{2} \mathrm{Cu}_{2} \mathrm{Cl}_{6}$ and $\mathrm{K}_{2} \mathrm{Cu}_{2} \mathrm{Br}_{6}$, respectively ${ }^{11}$.

Table I

Copper-halogen stretching frequencies in $\mathrm{cm}^{-1}$

\begin{tabular}{|c|c|c|}
\hline & $(\mathrm{Cu}-\mathrm{X})$ & $\left(\mathrm{Cu}-\mathrm{X}_{\mathbf{b}}\right)$ \\
\hline 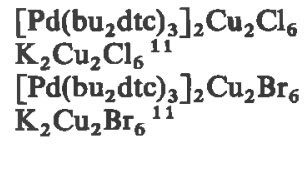 & $\begin{array}{ll}310 \text { (broad) } \\
301 & 193 \\
245 & \\
237 & 122 \\
t=\text { terminal } & \end{array}$ & $\begin{array}{ll}275 & 240 \\
278 & 236 \\
223 & \\
224 & \\
\text { b }=\text { bridged } & \end{array}$ \\
\hline
\end{tabular}

In contrast to the palladium compounds the platinum compounds contain two halogen atoms per formula unit. It is reasonable to assume $\left[\mathrm{CuCl}_{2}\right]^{-},\left[\mathrm{CuBr}_{2}\right]^{-}$, and $\left[\mathrm{AuBr}_{2}\right]^{-}$to be present in these complexes. In view of the linear structure of these ions $\left(D_{\infty h}\right)$ two metal halogen modes are infrared active, $\Sigma_{u}^{+}$and $\Pi_{u}$.

For $\left[\mathrm{AuCl}_{2}\right]^{-}$the $\Sigma_{\mathrm{u}}^{+}$absorption is found at $340 \mathrm{~cm}^{-112}$. Considering the mass effect only, the calculated values should be $393 \mathrm{~cm}^{-1}$ for $\left[\mathrm{CuCl}_{2}\right]^{-}, 313 \mathrm{~cm}^{-1}$ for $\left[\mathrm{CuBr}_{2}\right]^{-}$and $248 \mathrm{~cm}^{-1}$ for $\left[\mathrm{AuBr}_{2}\right]^{-}$.

10 P. H. Vossos, L. D. Jennings and R. E. Rundle, J. Chem. Phys. 32, 1590 (1963).

P. H. Vossos, D. R. Fitzwater and R. E. Rundle, Acta Cryst. 16, 1037 (1963).

R. D. Willett, C. Dwiggins, R. F. Kruh and R. E. Rundle, J. Chem. Phys. 38, 2429 (1963).

11 D. M. Adams and P. J. Lock, J. Chem. Soc. (A) 620 (1967).

12 D. M. Adams, Metal-Ligand and Related Vibrations, E. Arnold Ltd, London (1967). 
Absorption bands found at $407 \mathrm{~cm}^{-1}$ for $\mathrm{Pt}\left(\mathrm{bu}_{2} \mathrm{dtc}\right)_{3} \mathrm{CuCl}_{2}$, at $325 \mathrm{~cm}^{-1}$ for $\mathrm{Pt}\left(\mathrm{bu}{ }_{2} \mathrm{dtc}\right)_{3} \mathrm{CuBr}_{2}$ and at $253 \mathrm{~cm}^{-1}$ for $\mathrm{Pt}\left(\mathrm{bu}_{2} \mathrm{dtc}\right)_{3} \mathrm{AuBr}_{2}$ are therefore ascribed to the asymmetric metal-halogen stretching frequencies $\left(\Sigma_{u}^{+}\right)$. The $\Pi_{u}$ frequencies are expected to lie in region below $200 \mathrm{~cm}^{-1}$.

The $\mathrm{C}-\mathrm{N}$ and $\mathrm{M}-\mathrm{S}$ stretching frequencies of the complexes are in good agreement with those found in the metal trisdithiocarbamato complexes with bromide and iodide as anions. ${ }^{9}$. The metal-sulfur stretching frequencies in the metaltrisdithiocarbamato complexes of nickel, palladium and platinum are given in Table II. Considering only the sulfur atoms around the central metal atom, the coordination symmetry is nearly $\mathrm{O}_{\mathrm{h}}$, and only one normal vibration belonging to a $\mathrm{M}-\mathrm{S}$ stretching frequency is expected to be found. In this way Brinkhoff ${ }^{6}$ ascribes the $387 \mathrm{~cm}^{-1}$ absorption band in $\left[\mathrm{Ni}\left(\mathrm{bu}_{2} \mathrm{dtc}\right)_{3}\right]^{+}$to the $\mathrm{Ni}-\mathrm{S}$ stretching frequency. When however the $\mathbf{R}_{2} \mathbf{N C}$ chain is taken into account, the symmetry is $D_{3}$. In that case three normal modes of vibration belonging to the $\mathbf{M}-\mathbf{S}$ stretching frequency are infrared active $\left(A_{2}+2 E\right)$. Assuming the $M-S$ stretching frequencies to be subject to mass changes only, we found in the trisdithiocarbamates of nickel, palladium and platinum, three absorption peaks with a remarkable agreement between the observed and calculated values when the spectrum of $\left[\mathrm{Pd}\left(\mathrm{bu}_{2} \mathrm{dtc}\right)_{3}\right]^{+}$was used as a standard for calculation. Furthermore the calculated values of the Ni-Se stretching frequencies correspond to the absorption bands found in the spectrum of nickel $\operatorname{tris}(N, N$-di-n-butyl-diselenocarbamato) bromide.

Though we do not imply these frequencies to be of pure metal chalcogen character, the agreement suggests similar pseudo-octahedral structures for the tris-dithiocarbamato ions of nickel, palladium and platinum.

Table II

$\mathrm{M}-\mathrm{S}$ stretching frequencies of $\left[\mathrm{M}\left(\mathrm{bu}_{2} \mathrm{dtc}\right)_{3}\right]^{+}$and $\mathrm{M} \longrightarrow \mathrm{Se}$ stretching frequencies of $\left[\mathrm{Ni}\left(\mathrm{bu}_{2} \mathrm{dsc}\right)_{3}\right]^{+}$in $\mathrm{cm}^{-1}$.

Calculated values of $\mathrm{M}-\mathrm{S}$ and $\mathrm{M}-\mathrm{Se}$ with $\left[\mathrm{Pd}\left(\mathrm{bu}_{2} \mathrm{dtc}\right)_{3}\right]^{+}$as a standard, are given in parentheses.

\begin{tabular}{|cc|c|cc|cc|}
\hline \multicolumn{2}{|c|}{$\left[\mathrm{Ni}\left(\mathrm{bu}_{2} \mathrm{dtc}\right)_{3}\right]^{+}$} & {$\left[\mathrm{Pd}\left(\mathrm{bu}_{2} \mathrm{dtc}\right)_{3}\right]^{+}$} & \multicolumn{2}{|c|}{$\left[\mathrm{Pt}\left(\mathrm{bu} \mathrm{dttc}_{3}\right]^{+}\right.$} & \multicolumn{2}{|c|}{$\left[\mathrm{Ni}\left(\mathrm{bu} \mathrm{dsc}_{2}\right]^{+}\right.$} \\
\hline 410 & $(417)$ & 383 & 365 & $(362)$ & 327 & $(327)$ \\
387 & $(392)$ & 360 & 341 & $(341)$ & 317 & $(308)$ \\
370 & $(362)$ & 333 & & $(315)$ & 284 & $(284)$ \\
\hline
\end{tabular}


The magnetic measurements of the platinum compounds $\left[\mathrm{Pt}\left(\mathrm{bu}_{2} \mathrm{dtc}\right)_{3}\right]^{+}\left[\mathrm{CuCl}_{2}\right]^{-}, \quad\left[\mathrm{Pt}\left(\mathrm{bu}_{2} \mathrm{dtc}\right)_{3}\right]^{+}\left[\mathrm{CuBr}_{2}\right]^{-}$and $[\mathrm{Pt}-$ $\left.\left(\mathrm{bu}_{2} \mathrm{dtc}\right)_{3}\right]^{+}\left[\mathrm{AuBr}_{2}\right]^{-}$reveal high momentums, which are nearly temperature independent.

Table III

Molar magnetic susceptibilities $\mathrm{X}_{\mathrm{m}}$ in cgs units of some platinum bis $(N, N$-di- $n$-butyldithiocarbamato) compounds, corrected for diamagnetism.

\begin{tabular}{|c|c|c|}
\hline & $\mathrm{T}=293^{\circ} \mathrm{K}$ & $\mathrm{T}=113^{\circ} \mathrm{K}$ \\
\hline $\mathrm{Pt}\left(\mathrm{bu}_{2} \mathrm{dtc}\right)_{3} \mathrm{CuCl}_{2}$ & $665 \cdot 10^{-6}$ & $755 \cdot 10^{-6}$ \\
$\mathrm{Pt}\left(\mathrm{bu}_{2} \mathrm{dtc}\right)_{3} \mathrm{CuBr}_{2}$ & $804 \cdot 10^{-6}$ & $955 \cdot 10^{-6}$ \\
$\mathrm{Pt}\left(\mathrm{bu}_{2} \mathrm{dtc}\right)_{3} \mathrm{AuBr}_{2}$ & $459 \cdot 10^{-6}$ & $461 \cdot 10^{-6}$ \\
\hline
\end{tabular}

More often we found complexes of nickel, palladium and platinum with dithiocarbamato ligands to have such a high susceptibility. This phenomenon is currently under investigation.

The NMR spectra of the platinum compounds investigated, measured at different temperatures, show remarkable similarity to those of $\left[\mathrm{Ni}\left(\mathrm{bu}_{2} \mathrm{dtc}\right)_{3}\right]^{+} \mathrm{Br}^{-}$, giving evidence that in the platinum compounds the ligand is also present as dithiocarbamate and not as thiuram disulfide $^{13} . \tau$-values are given in Table IV.

Table IV

NMR proton resonances. $\tau$ in $\mathrm{ppm}$. Temperature $33^{\circ}$

\begin{tabular}{|l|l|l|l|l|}
\hline & \multicolumn{4}{|c|}{$\mathrm{CH}_{3}-\mathrm{CH}_{2}-\mathrm{CH}_{2}-\mathrm{CH}_{2}-\mathrm{N}$} \\
\hline $\mathrm{Pt}\left(\mathrm{bu}_{2} \mathrm{dtc}\right)_{3} \mathrm{CuCl}_{2}$ & 8.56 & 8.12 & 7.80 & 5.96 \\
$\mathrm{Pt}\left(\mathrm{bu}_{2} \mathrm{dtc}\right)_{3} \mathrm{CuBr}_{2}$ & 8.56 & 8.12 & 7.78 & 5.94 \\
$\mathrm{Pt}\left(\mathrm{bu}_{2} \mathrm{dtc}\right)_{3} \mathrm{AuBr}_{2}$ & 8.56 & 8.14 & 7.80 & 5.94 \\
$\mathrm{Pt}\left(\mathrm{bu}_{2} \mathrm{dtc}\right)_{3} \mathrm{I}_{3}{ }^{9}$ & 8.58 & 8.14 & 7.80 & 5.97 \\
$\mathrm{Ni}\left(\mathrm{bu}_{2} \mathrm{dtc}\right)_{3} \mathrm{Br}$ & 8.72 & 8.30 & 7.98 & 6.08 \\
\hline
\end{tabular}

13 A. Avdeef, J. P. Fackler Jr. and R. G. Fischer Jr., J. Am. Chem. Soc. 92, 6972 (1970). 
Molar conductivity measurements show the complexes to be $1: 1$ electrolytes. The values found for $\Lambda_{0}$ are given in Table V. The dependence of the molar conductivity on the square root of the concentration gives a straight line. The slope of this line, $A=\frac{\Lambda_{0}-\Lambda}{\sqrt{c}}$ is characteristic of this type of electrolytes. From the relation $A=\alpha \Lambda_{0}+\beta$, with $\alpha=0.779$ and $\beta=44.2^{14}$ at $25^{\circ}$, theoretical values can be computed. The experimental and calculated values, including the data for $\mathrm{Pt}\left(\mathrm{bu}_{2} \mathrm{dtc}\right)_{3} \mathrm{Br}$ are given in Table $\mathrm{V}$.

\section{Table V}

Conductivity data in nitrobenzene at $25^{\circ} \mathrm{C}$. $\Lambda_{0}$ in $\Omega^{-1} \mathrm{~cm}^{2} \mathrm{~mole}^{-1}$.

\begin{tabular}{|c|c|c|c|}
\hline & $\Lambda_{0}$ & $A_{\text {exp }}$ & $\mathbf{A}_{\mathrm{catc}}$ \\
\hline $\begin{array}{l}{\left[\mathrm{Pt}\left(\mathrm{bu}_{2} \mathrm{dtc}\right)_{3}\right]^{+}\left[\mathrm{CuCl}_{2}\right]^{-}} \\
{\left[\mathrm{Pt}^{-}\left(\mathrm{bu}_{2} \mathrm{dtc}\right)_{3}\right]^{+}\left[\mathrm{CuBr}_{2}\right]^{-}} \\
\left.\left[\mathrm{CuBt}_{2} \mathrm{dtc}\right)_{3}\right]^{+}\left[\mathrm{AuBr}_{2}\right]^{-} \\
{\left[\mathrm{Pt}\left(\mathrm{bu}_{2} \mathrm{dtc}\right)_{3}\right]^{+} \mathrm{Br}^{-}{ }^{-}}\end{array}$ & $\begin{array}{l}28.9 \\
28.2 \\
29.6 \\
28.8\end{array}$ & $\begin{array}{l}56 \\
55 \\
62 \\
66\end{array}$ & $\begin{array}{l}67 \\
67 \\
68 \\
67\end{array}$ \\
\hline
\end{tabular}

From $\Lambda_{0}$ of $\left[\mathrm{Pt}\left(\mathrm{bu}_{2} \mathrm{dtc}\right)_{3}\right]^{+} \mathrm{Br}^{-}$and $\lambda_{0}^{-}$of $\mathrm{Br}^{-}\left(21.9 \Omega^{-1} \mathrm{~cm}^{2}\right.$ mole $\left.{ }^{-1}\right)$ the equivalent conductivity of the $\left[\mathrm{Pt}\left(\mathrm{bu}_{2} \mathrm{dtc}\right)_{3}\right]^{+}$ion, $\lambda_{0}^{+}$, can be calculated. This value 6.9 is higher than the one calculated for the $\left[\mathrm{Ni}\left(\mathrm{bu}_{2} \mathrm{dtc}\right)_{3}\right]^{+}$ion $(3.5)^{6}$. This discrepancy is not very serious in view of the normal error in the measurements. The $\lambda_{\mathrm{o}}^{-}$values of $\left[\mathrm{CuCl}_{2}\right]^{-}$, $\left[\mathrm{CuBr}_{2}\right]^{-}$and $\left[\mathrm{AuBr}_{2}\right]^{-}$are 22.0, 21.5 and 22.7, respectively. The $\lambda_{0}^{-}$value for $\left[\mathrm{AuBr}_{2}\right]^{-}$in $\left[\mathrm{Au}\left(\mathrm{bu}_{2} \mathrm{dtc}\right)_{2}\right]^{+}\left[\mathrm{AuBr}_{2}\right]^{-}$is found to be $21.0^{15}$.

From the results reported, the general conclusion can be drawn that the compounds of the type $\left[M\left(R_{2} d t c\right)_{3}\right]^{+} X^{-}(M=N i, P d, P t)$ can be prepared from $\mathbf{M}\left(\mathbf{R}_{2} \mathrm{dtc}\right)_{2}$ in various ways. The type of anion depends on the metal and the oxidant used. The $\left[\mathrm{Pd}\left(\mathrm{R}_{2} \mathrm{dtc}\right)_{3}\right]^{+}$and $\left[\mathrm{Pt}\left(\mathbf{R}_{\mathbf{2}} \mathrm{dtc}\right)_{3}\right]^{+}$ions seem to be isostructural with $\left[\mathrm{Ni}\left(\mathbf{R}_{\mathbf{2}} \mathrm{dsc}\right)_{3}\right]^{+16}$ and

${ }^{14}$ E. G. Taylor and C. A. Kraus, J. Am. Chem. Soc. 69, 1731 (1947).

15 J. G. M. van der Linden, Rec. Trav. Chim. 90, 1027 (1971).

16 P. T. Beurskens and J. A. Cras, J. Cryst. Mol. Struct. 1, 63 (1971). 
$\left[\mathrm{Ni}\left(\mathrm{R}_{2} \mathrm{dtc}\right)_{3}\right]^{+15}$ in which the $\mathrm{Ni}$ atom is octahedrally coordinated with $6 \mathrm{Se}$ and $6 \mathrm{~S}$ atoms, respectively, as is revealed by X-ray studies.

\section{Acknowledgement}

The authors wish to thank Professor J. J. Steggerda for his continuous interest in this work.

(Received January 14th, 1972) 